\section{Germination and Storage of Vinca Seed Is Influenced by Light, Temperature, and Relative Humidity}

\author{
William J. Carpenter
}

Environmental Horticulture Department, University of Florida, Institute

of Food and Agricultural Sciences, Gainesville, FL 32611

\section{Joseph F. Boucher \\ Department of Statistics, Institute of Food and Agricultural Sciences, Gainesville, FL 32611}

Additional index words. Catharanthus roseus, dark germination, seed cold and moisture tolerance, storage relative humidity

\begin{abstract}
Light, temperature, relative humidity (RH), and $\mathbf{G A}_{3}$ affect vinca [Catharanthus roseus (L.) G. Don] seed storage and/or germination. GA failed to increase the germination percentage in darkness but significantly increased the percentage in continuous light. Similarly, $\mathbf{G A}_{3}$ treatment reduced both the number of days required to achieve $50 \%$ of the final germination percentage $\left(T_{50}\right)$ and the span between $10 \%$ and 90\% germination $\left(\mathrm{T}_{90}-\mathrm{T}_{10}\right)$ for seeds in light, but not in darkness. Germination percentages were maximal and about equal at 25,30 , or $35 \mathrm{C}$ in darkness; germination was lowest below $25 \mathrm{C}$. Germination $T_{50}$ and $T_{90}-T_{10}$ required the fewest days between 25 and 35C. Reducing seed moisture from $9.9 \%$ to $3.9 \%$ increased the $\mathrm{T}_{30}$ from 2.4 to 3.0 days but failed to change germination percentages. Germination percentage declined linearly as seed storage temperatures were reduced from 5 to $-20 \mathrm{C}$, whereas days to $T_{50}$ increased. Seed storage for 12 months without reduction in germination percentage was possible at $5 \mathrm{C}$ and $11 \%, 33 \%$, or $52 \% \mathrm{RH}$, but storage at $75 \%$ or $95 \% \mathrm{RH}$ for periods exceeding 1 month reduced germination. Seeds stored at $33 \%$ or $52 \% \mathrm{RH}$ required fewer days to $\mathrm{T}_{50}$ than did seeds stored at $11 \%, 75 \%$, or $95 \% \mathrm{RH}$. Chemical name used: gibberellic acid $\left(\mathbf{G A}_{3}\right)$.
\end{abstract}

Vinca, a perennial, is generally grown as an annual bedding plant. Propagation is by seed, with optimal germination temperature ranging from 20 to $27 \mathrm{C}$ (Mastalerz, 1976; Styer and Laffe, 1990). Carlson (1986) reported that germination ceases when the temperatures fall below $15 \mathrm{C}$ or the medium becomes slightly dry. Vinca seed is sensitive to light during germination. Mastalerz (1976) and Ball (1991) recommended that the seed be covered lightly with the sowing medium and kept in darkness during germination. Bewley and Black (1982) classified plant species in terms of light sensitivity during germination, according to whether dormancy was terminated or germination was inhibited by light. Mayer and Poljakoff-Mayber (1979) reported that the light response of seeds from sensitive plant species increased with time during imbibition, with lettuce (Lactuca sativa L.) reaching maximum sensitivity about $1 \mathrm{~h}$ after completing imbibition. Bewley and Black (1982) found that periods of light sensitivity during germination were similar for seeds of species requiring light or darkness.

Received for publication 18 Sept. 1991. Accepted for publication 3 Apr. 1992. Florida Agricultural Experiment Station Journal Series no. R-01843. This research was partially supported by a grant from the Bedding Plants Foundation, Inc. The cost of publishing this paper was defrayed in part by the payment of page charges. Under postal regulations, this paper therefore must be hereby marked advertisement solely to indicate this fact.
Our research objectives were to determine the effects of relative humidity $(\mathrm{RH})$ during seed storage and of temperature and light on germination.

Temperature for germination. Vinca seeds of 'Grape Cooler', 'Peppermint Cooler', and 'Pretty in Rose', harvested 17 Dec. 1989 (Denholm Seeds, Lompoc, Calif.), were received 26 Dec. 1989 and dusted with $3 \alpha, 4,7,7 \alpha$-tetrahydro-2-[(trichloromethyl) thio]-1H-isoindole-1,3(2H)-dione (captan). The treatments contained four 100 -seed replicates, with seeds of each germinated in in-
'Days to $50 \%$ of final germination.

'Days from $10 \%$ to $90 \%$ of final germination. dividual 9-cm petri dishes on a double layer of Whatman No. 1 filter paper moistened with $5 \mathrm{ml}$ distilled water (DW). Seeds were germinated in dark incubators at constant 15 , $20,25,30$, or $35 \mathrm{C}$, and germination counts were made in darkness with $0.21 \mathrm{~mol} \cdot \mathrm{m}^{-2} \cdot \mathrm{s}^{-1}$ of photosynthetically active radiation from a green lamp. Temperature-controlled incubators (model CB-1; Stults Scientific Engineering Corp., Springfield, Ill.) were used in the study. Daily germination counts were made of seeds with visible radicle protrusion through the testa. Total germination percentage $(G)$, days to $50 \%$ of the final germination percentage $\left(\mathrm{T}_{50}\right)$, and germination span, in number of days elapsed between $10 \%$ and $90 \%$ germination $\left(T_{90}-T_{10}\right)$, were calculated in all studies, as recommended by Furutani et al. (1985). The design was a split plot; data were tested by analyses of variance (ANOVA), and trends in temperature were determined through orthogonal contrasts (Steel and Torrie, 1960).

Gibberellin and germination in light or in darkness. Seeds of 'Grape Cooler', 'Peppermint Cooler', and 'Pretty in Rose' were placed for $6 \mathrm{~h}$ in $9-\mathrm{cm}$ petri dishes on two Whatman No. 1 filter papers wetted with 10 $\mathrm{ml}$ of DW or $10 \mathrm{ml}$ of $1000 \mathrm{ppm} \mathrm{GA}$. After imbibition, all seeds were removed, blotted dry, and transferred to petri dishes with filter papers moistened by $5 \mathrm{ml} \mathrm{DW}$. Treatments (four replications of 100 seeds) imbibed in DW or in $\mathrm{GA}_{3}$ were germinated with $24 \mathrm{~h}$ of irradiation (60-W incandescent lamps at $\left.75 \mu \mathrm{mol} \cdot \mathrm{m}^{-2} \cdot \mathrm{s}^{-1}\right)$ or in darkness at $25 \mathrm{C}$. Seeds with emerged radicles were counted daily for 21 days; $G, T_{50}$, and $T_{90}-T_{10}$ were calculated. The design was a split plot, and ANOVA were conducted for light and dark as the main plots and $\mathrm{GA}_{3}$ treatments as the subplots. Separate analyses were made for each cultivar. Differences among treatments were determined using Fisher's LSD procedure (Milliken and Johnson, 1984) at $P=0.05$.

Seed moisture content. Four 100-seed lots of the freshly harvested ' $G$ rape Cooler' vinca were weighed, dehydrated at $105 \mathrm{C}$ for $48 \mathrm{~h}$, and reweighed after cooling to determine the

Table 1. The effect of gibberellic acid (GA) on vinca seed germination in light or in darkness at 25C. A separate analysis was conducted with the data from each cultivar. Data are the means of 400 seeds.

\begin{tabular}{|c|c|c|c|c|}
\hline \multirow[b]{2}{*}{ Cultivar } & \multirow[b]{2}{*}{ Treatment } & \multicolumn{3}{|c|}{ Germination $^{z}$} \\
\hline & & $\begin{array}{c}\text { Total } \\
(\%)\end{array}$ & $\begin{array}{c}\mathrm{T}_{50}{ } \\
\text { (days) }\end{array}$ & $\begin{array}{l}\text { Span }^{x} \\
\text { (days) }\end{array}$ \\
\hline Grape Cooler & $\begin{array}{l}\text { Dark } \\
\text { Dark + GA } \\
\text { Light } \\
\text { Light }+\mathrm{GA}\end{array}$ & $\begin{array}{r}100 \mathrm{a} \\
97 \mathrm{a} \\
71 \mathrm{~b} \\
87 \mathrm{a}\end{array}$ & $\begin{array}{l}1.9 \mathrm{~b} \\
2.0 \mathrm{~b} \\
4.1 \mathrm{a} \\
3.8 \mathrm{a}\end{array}$ & $\begin{array}{l}1.8 \mathrm{c} \\
2.0 \mathrm{c} \\
5.2 \mathrm{a} \\
4.6 \mathrm{~b}\end{array}$ \\
\hline Peppermint Cooler & $\begin{array}{l}\text { Dark } \\
\text { Dark + GA } \\
\text { Light } \\
\text { Light + GA }\end{array}$ & $\begin{array}{l}96 \mathrm{a} \\
98 \mathrm{a} \\
75 \mathrm{~b} \\
96 \mathrm{a}\end{array}$ & $\begin{array}{l}1.9 \mathrm{c} \\
1.7 \mathrm{c} \\
3.4 \mathrm{a} \\
2.2 \mathrm{~b}\end{array}$ & $\begin{array}{l}2.0 \mathrm{bc} \\
1.6 \mathrm{c} \\
3.3 \mathrm{a} \\
2.4 \mathrm{~b}\end{array}$ \\
\hline Pretty in Rose & $\begin{array}{l}\text { Dark } \\
\text { Dark + GA } \\
\text { Light } \\
\text { Light }+ \text { GA }\end{array}$ & $\begin{array}{l}81 \mathrm{a} \\
82 \mathrm{a} \\
65 \mathrm{~b} \\
83 \mathrm{a}\end{array}$ & $\begin{array}{l}2.4 \mathrm{~b} \\
2.7 \mathrm{~b} \\
3.3 \mathrm{a} \\
2.7 \mathrm{~b}\end{array}$ & $\begin{array}{l}2.8 \mathrm{~b} \\
2.8 \mathrm{~b} \\
3.9 \mathrm{a} \\
2.8 \mathrm{~b}\end{array}$ \\
\hline
\end{tabular}

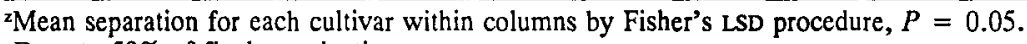



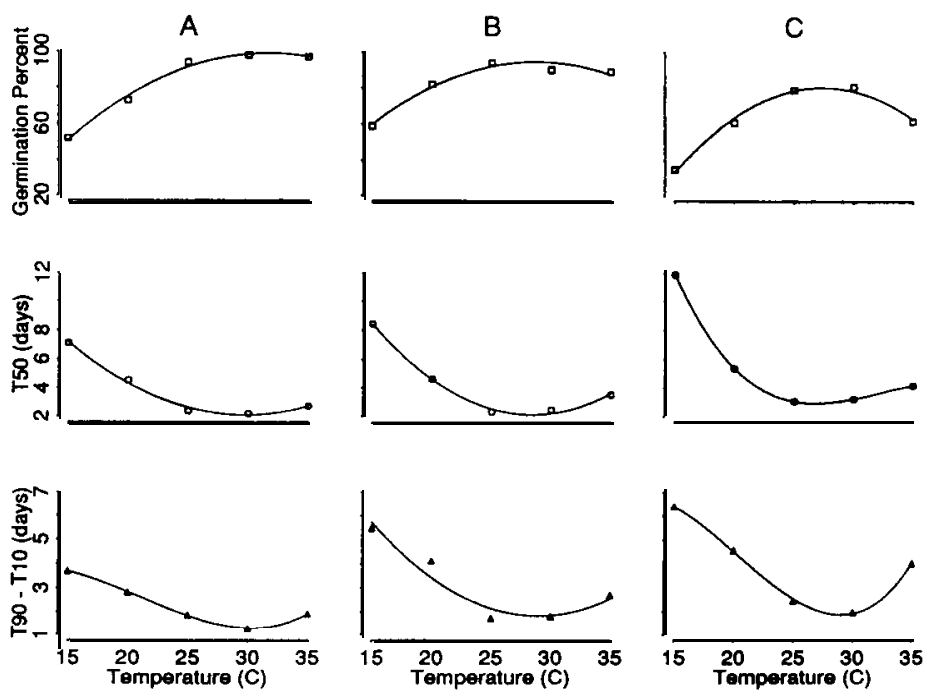

Fig. 1. Temperature influence on germination percentage $(\mathrm{G})$, days to $50 \%$ of final germination $\left(\mathrm{T}_{50}\right)$, and span in days between $10 \%$ and $90 \%$ germination $\left(\mathrm{T}_{90}-\mathrm{T}_{10}\right)$ for three cultivars of vinca. The orthogonal polynomial contrast used to determine the trends in temperature were:

$$
\begin{aligned}
& \text { (A) Grape Cooler: } \\
& \hat{\mathrm{G}}=-56.3+10.5 \times \mathrm{Temp}-0.18 \times \mathrm{Temp}^{2} ; R^{2}=0.69 \\
& \hat{\mathrm{T}}_{50}=30.3+2.0 \times \mathrm{Temp}+0.04 \times \mathrm{Temp}^{2} ; R^{2}=0.98 \\
& \hat{S}_{\text {pan }}=18.6-1.2 \times \text { Temp }+0.02 \times \text { Temp }^{2} ; R^{2}=0.83 \\
& \text { (B) Peppermint Cooler: } \\
& \hat{\mathrm{G}}=-74.9+11.0 \times \mathrm{Temp}-0.17 \times \mathrm{Temp}^{2} ; R^{2}=0.87 \\
& \hat{\mathrm{T}}_{\mathrm{so}}=22.8+1.4 \times \mathrm{Temp}+0.02 \times \mathrm{Temp}^{2} ; R^{2}=0.89 \\
& \hat{S}_{\text {pan }}=-1.2+1.0 \times \text { Temp }-0.06 \times \mathrm{Temp}^{2} ; R^{2}=0.89 \\
& \text { (C) Pretty in Rose: } \\
& \hat{\mathrm{G}}=-147.5+16.6 \times \mathrm{Temp}-0.30 \times \mathrm{Temp}^{2} ; R^{2}=0.72 \\
& \hat{T}_{s 0}=74.3-7.0 \times \mathrm{Temp}+0.23 \times \mathrm{Temp}^{2} ; R^{2}=0.98 \\
& \hat{S}_{\text {pan }}=-2.3+1.86 \times \mathrm{Temp}-0.11 \times \mathrm{Temp}^{2} ; R^{2}=0.89
\end{aligned}
$$

\begin{tabular}{|c|c|c|c|c|c|}
\hline \multicolumn{6}{|c|}{ Seed storage at $5 \mathrm{C}$} \\
\hline \multirow{2}{*}{$\begin{array}{l}\text { RH } \\
(\%) \\
\end{array}$} & \multirow{2}{*}{$\begin{array}{c}\text { Seed moisture } \\
(\%)\end{array}$} & \multicolumn{4}{|c|}{ Months } \\
\hline & & 1 & 4 & 8 & 12 \\
\hline & & \multicolumn{4}{|c|}{ Germination (\%) } \\
\hline 11 & 4 & 88 & 90 & 91 & 93 \\
\hline 33 & 6 & 92 & 93 & 89 & 94 \\
\hline 52 & 8 & 94 & 91 & 92 & 88 \\
\hline 75 & 11 & 90 & 84 & 68 & 13 \\
\hline 95 & 15 & 73 & 28 & 11 & 0 \\
\hline \multicolumn{6}{|l|}{ Significance } \\
\hline Moisture (M) & \multicolumn{2}{|c|}{$* *$} & & & \\
\hline Storage period (SP) & \multicolumn{2}{|c|}{$*$} & & & \\
\hline \multirow[t]{2}{*}{$\mathrm{M} \times \mathrm{SP}$} & \multicolumn{2}{|l|}{ * } & & & \\
\hline & & \multicolumn{4}{|c|}{ Days to $50 \%$ of germination } \\
\hline 11 & 4 & 3.5 & 3.8 & 4.0 & 4.3 \\
\hline 33 & 6 & 3.4 & 3.1 & 3.2 & 3.3 \\
\hline 52 & 8 & 3.2 & 3.3 & 3.0 & 2.9 \\
\hline 75 & 11 & 3.7 & 3.9 & 5.2 & 5.5 \\
\hline 95 & 15 & 3.9 & 4.5 & 7.1 & - \\
\hline \multicolumn{6}{|l|}{ Significance } \\
\hline Moisture (M) & *** & & & & \\
\hline Storage period (SP) & $* *$ & & & & \\
\hline $\mathrm{M} \times \mathrm{SP}$ & $*$ & & & & \\
\hline
\end{tabular}

Table 2. Influence of seed storage relative humidity and duration on the germination percentage and days to $50 \%$ of final germination of 'Grape Cooler' vinca.

****Significant at $P=0.05$ or 0.01 , respectively; data are the means of 400 seeds.

initial moisture content. Other treatments were weighed, placed in open $9-\mathrm{cm}$ petri dishes, and dehydrated in forced-draft ovens at $40 \mathrm{C}$ for $1,2,4,8,12,24$, or $48 \mathrm{~h}$. After dehydration, seeds were reweighed and immedi- ately germinated, as previously described, at $25 \mathrm{C}$ in darkness. A split plot ANOVA was used, with duration of dehydration as the main plot and seed moisture as the subplot. Orthogonal polynomial contrasts were used to determine seed moisture trends.

Storage temperature. Seeds were stored for 1 week in $15 \times 2.5 \mathrm{~cm}$ petri dishes on wire screens supported by segments of tubing $1 \mathrm{~cm}$ above a chemical desiccant that reduced the $9.9 \%$ moisture content of freshly harvested 'Grape Cooler' seed to $7.2 \%$. Constant $22 \% \mathrm{RH}$ was maintained in sealed petri dishes by addition of $50 \mathrm{ml}$ of saturated potassium acetate to the bottom of each dish (Copeland, 1976). The incubator was maintained at $15 \mathrm{C}$ during the week of reduced seed hydration. After dehydration, seeds were weighed, placed immediately into 10 -ml glass vials, which were then sealed, and immersed in a controlled-temperature polyethylene glycol-water (v/v) bath (Guy and Carter, 1984) held at $5,0,-5,-10,-15$, or -20C. Bath temperatures were lowered $3 \mathrm{C} /$ $\mathrm{h}$ to final temperatures, held there for 7 days, then increased $4 \mathrm{C} / \mathrm{h}$ to $10 \mathrm{C}$. Following lowtemperature treatment, seeds were germinated in darkness at $25 \mathrm{C}$. Germination counts were made daily of seeds with radicle protrusion through the testa. Data were analyzed by ANOVA, and orthogonal contrasts were used to determine temperature trends (Steel and Torrie, 1960).

Relative humidity during and duration of seed storage. Freshly harvested seed of 'Grape Cooler' was dusted with captan and stored at $5 \mathrm{C}$ and various relative humidities for 1 , 4,8 , or 12 months. Humidity treatments were achieved using saturated lithium chloride, magnesium chloride, magnesium nitrate, sodium chloride, or potassium nitrate, as described previously, to achieve $11 \%, 33 \%$, $52 \%, 75 \%$, or $95 \%$ RH levels, respectively. Four 100-seed replications were germinated in darkness at $25 \mathrm{C}$ immediately after storage at each duration and at each RH level, whereas another four replications were desiccated for $48 \mathrm{~h}$ in forced-draft ovens at $105 \mathrm{C}$ to determine moisture contents of stored seed. The design was a $4 \times 5$ factorial arranged in a randomized complete block, and data were analyzed by ANOVA.

Vinca seeds required high temperature and darkness for best germination (Fig. 1 and Table 1, respectively). Total germination percentages for 'Grape Cooler' and 'Peppermint Cooler' were similar at 25, 30, and 35C and for 'Pretty in Rose' at 25 and 30C. Contrasts were perfomed by comparing the average response at the high temperatures (25, 30 , and 35C) for 'Grape Cooler' and 'Peppermint Cooler' and at 25 and $30 \mathrm{C}$ for 'Pretty in Rose' against the average response at the two lower temperatures (15 and 20C). For all cultivars, $\mathrm{G}$ at temperatures below $25 \mathrm{C}$ was significantly $(P<0.01)$ lower than at higher temperatures (Fig. 1). The number of days to achieve $\mathrm{T}_{50}$ at 25,30 , and $35 \mathrm{C}$ was significantly $(P<0.01)$ lower than below $25 \mathrm{C}$ for all cultivars (Fig. 1). The $\mathrm{T}_{90}-\mathrm{T}_{10}$ were significantly $(P<0.01)$ shorter for 'Grape Cooler' and 'Peppermint Cooler' at 25,30 , and $35 \mathrm{C}$ and for 'Pretty in Rose' at 25 and $30 \mathrm{C}$ than at the other temperatures (Fig. 1). These results indicate that vinca seed needs higher germination temperatures than the 20 to $25 \mathrm{C}$ recommended by Mas- 


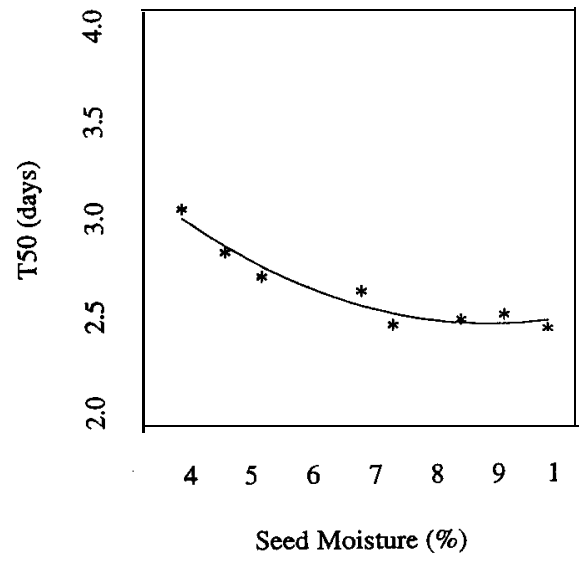

Fig. 2. Seed moisture content of 'Grape Cooler' vinca in relation to days to $50 \%$ of final germination $\left(\mathrm{T}_{50}\right)$. The regression equation was: $\mathrm{T}_{50}=4.19-0.39+0.218 \times \mathrm{S} \mathrm{M}^{2} ; R^{2}=$ 0.60 .
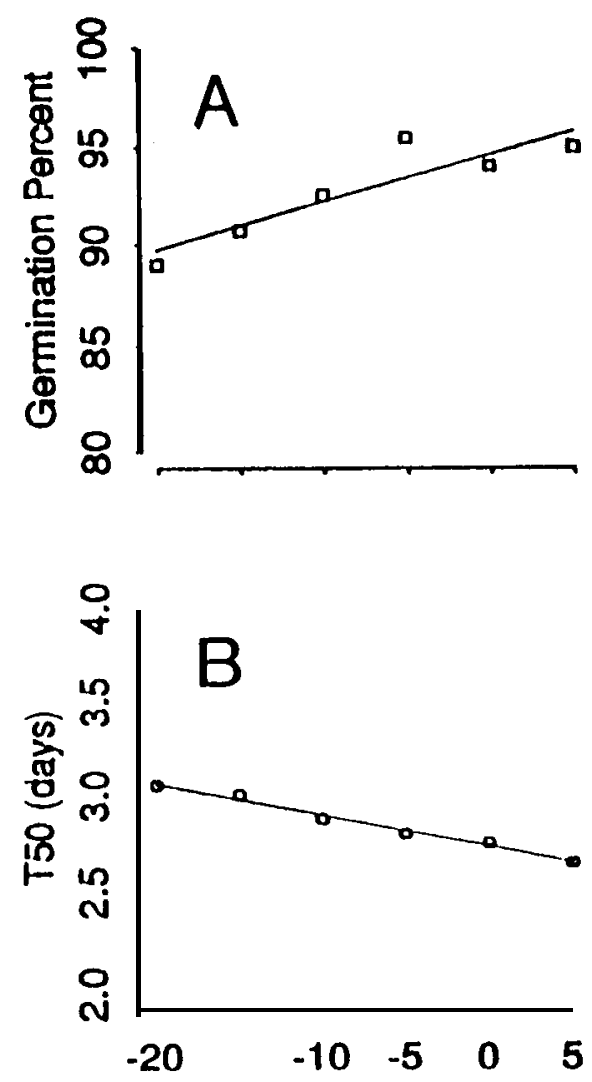

Temperature (C)

Fig. 3. Storage of 'Grape Cooler' vinca seed at freezing temperatures in relation to (A) total germination percentages $(\mathrm{G})$ and $(\mathbf{B})$ days to $50 \%$ of final germination $\left(\mathrm{T}_{50}\right)$. The linear regression equations were: $\mathrm{G}=94.6+0.24$ $\times$ Temp, $R^{2}=0.42 ; \mathrm{T}_{50}=2.7-0.02 \times$ Temp, $R^{2}=0.45$.

talerz (1976) and Carlson (1986), and the temperature range is broader for highest total germination than that reported by Styer and Laffe (1990) and Ball (1991).

Vinca seed germination percentage was higher in darkness than in light, as also reported by Ball (1991). Total germination in darkness was not increased by the addition of GA, during seed imbibition (Table 1). GA significantly increased total gemination percentages of seeds in continuous light, with $\mathrm{GA}_{3}$ eliminating the need for darkness. Application of GA, had no effect on the $T_{50}$ or $\mathrm{T}_{90}-\mathrm{T}_{10}$ of seeds germinated in darkness, but it did in light (Table 1). Germination in light lengthened the periods to $\mathrm{T}_{50}$ and $\mathrm{T}_{90}$ $\mathrm{T}_{10}$ for seeds of each cultivar, but GA, treatment of seeds shortened both germination periods in light relative to those in darkness for 'Pretty in Rose'. GA treatment generally reduced the $T_{50}$ and $T_{90}-T_{10}$ for 'Grape Cooler' and 'Peppermint Cooler' seed germinated in light, but more days were required for germination in light than in darkness (Table 1). The capacity of GA, to allow the full germination of light- or dark-requiring seeds under unfavorable light conditions was reported by Chen and Thimann (1966). Cocucci et al. (1981) found that light inhibited the germination in dark-requiring Phacelia tanacetifolia Benth. seeds, but germination in light was promoted after seed pretreatment with acetone containing GA,

Seeds of 'Grape Cooler' tolerated desiccation, and no trend or difference occurred in $\mathrm{G}(89 \%$ to $93 \%)$ for seed moisture contents from $9.9 \%$ to $3.9 \%$ (data not presented). A quadratic trend was established when $\mathrm{T}_{50}$ values increased from 2.4 to 3.0 days as seed moisture levels declined (Fig. 2). Evidently, the level of seed desiccation during storage influenced the period required for germination. Justice and Bass (1978) report that the first indication of seed injury from low moisture content is delayed germination.

'Grape Cooler' seeds at $7.2 \%$ moisture content were cold-tolerant, but a linear increase in $\mathrm{G}$ occurred as storage temperature increased from -20 to $5 \mathrm{C}$ (Fig. 3A). Storage of seeds for longer than 7 days at any of the temperatures tested might reduce $G$ further. A linear decrease in the number of days to $T_{50}$ was found as seed storage temperatures increased (Fig. 3B). These results indicated that germination was delayed as seed storage temperatures declined. Subfreezing temperatures are superior to higher temperatures for the long-term storage of seeds because of lower seed respiration (Justice and Bass, 1978). Barton (1932) reported that Delphinium $\times$ cultorum Voss and Delphinium elatum L. seed had no significant loss in total germination or vigor after storage for 5 years at $-15 \mathrm{C}$.

Significant differences were found for $G$ and $\mathrm{T}_{50}$ for seed moisture (M) content during storage, the duration of the storage period (SP), and the interaction $\mathrm{M} \times \mathrm{SP}$. Seed storage for 12 months without reduction in $\mathrm{G}$ was possible at $5 \mathrm{C}$ and $11 \%, 33 \%$, or $52 \%$ $\mathrm{RH}$, but storage at $75 \%$ or $95 \% \mathrm{RH}$ for periods exceeding 1 month reduced $\mathrm{G}$ (Table 2 ). The seed moisture percentages shown (Table 2) are the means for seeds removed at each humidity level after storage for 1,4 , 8 , or 12 months. Seeds stored at $33 \%$ or $52 \%$ $\mathrm{RH}$ required fewer days to achieve $\mathrm{T}_{50}$ than did seeds stored at $11 \%, 75 \%$, or $95 \% \mathrm{RH}$ (Table 2).
Moisture in seeds is in equilibrium with the ambient relative humidity of the storage container. Seed moisture percentage at a given $\mathrm{RH}$ depends on the species storage reserves (Atwater, 1980). Seeds of vinca and of many other species are desiccation-tolerant and require low moisture levels for long-term storage. A $4 \%$ to $6 \%$ seed moisture content is considered favorable for the prolonged storage of these species (Hartmann et al., 1990). Bewley and Black (1982) reported that many species lose viability at moisture levels below $4 \%$, causing reduced germination rates or delayed germination. The significant delay in vinca germination after storage at $11 \%$ $\mathrm{RH}$ probably was due to excessive seed desiccation (4\% moisture). Comé (1980) found that the harmful effects of excessively low seed moisture level during storage could be mitigated by slow rehydration with saturated water vapor before sowing.

Bradbeer and Pinfield (1967) reported that the maximum seed viability of many species occurred when seeds were stored at $20 \%$ to $25 \% \mathrm{RH}$. Our results showed that vinca seed stored at $-33 \%$ and $52 \%$ RH had $6 \%$ and $8 \%$ moisture contents, respectively, and germinated significantly faster than at other levels, without a reduction in $\mathrm{G}$. Use of $5 \mathrm{C}$ made storage possible at these moisture levels. A rapid reduction in $\mathrm{G}$ occurred when vinca seed was stored at $75 \%$ or $95 \%$ RH. Hartmann et al. (1990) reported that seeds stored at high moisture levels had increased enzymatic activity and respiration, which hastened physiological deterioration.

This study presents new information for improving the environment during storage and germination of vinca seed. Germination percentages were highest at 25 to $35 \mathrm{C}$ in darkness, temperatures considerably warmer than those previously reported. The research also confirmed the need for darkness during germination, but seed treatment with gibberellins made germination percentages in light similar to those in darkness. Hartmann (1990) reported that gibberellins can relieve photodormancy in lettuce. seed by promoting germination without light; our results showed that for vinca gibberellins can replace the requirement for darkness. Several contributing factors were identified that affect the germination of vinca seed. Storing seed at high or low relative humidity (above $52 \%$ or below $11 \%$ ) or at subzero temperatures, or germinating seed at unfavorable temperatures contributed to irregular embryo emergence.

\section{Literature Cited}

Atwater, B.R. 1980. Germination, dormancy and morphology of the seeds of herbaceous ornamental plants. Seed Sci. \& Tech. 8:523-573.

Ball, V. 1991. Ball red book: Greenhouse growing. 15th ed. Geo. J. Ball Publishing, West Chicago, Ill.

Barton, L.V. 1932. Effect of storage on the viability of delphinium seeds. Boyce Thompson Inst. Contrib. 4:141-153.

Bewley, J.C. and M. Black. 1982. Physiology and biochemistry of seeds. Springer-Verlag, New York. 
Bradbeer, J.W. and N.J. Pinfield. 1967. Studies in seed dormancy. III. The effects of gibberellin on dormant seeds of Corylus avellana L. New Phytol. 66:515-523.

Carlson, W.H. 1986. A guideline for producing vinca. Greenhouse Gro. 4(5):12-13.

Chen, S.S.C. and K.V. Thimann. 1966. Nature of seed dormancy in Phacelia tanacetifolia. Science 153:1537-1539.

Cocucci, S., A.M. Ranieri, S. Morgutti, and F. Ciroli. 1981. The role of darkness. GA. and fusicoccin in breaking photodormancy in $P h a-$ celia tanacetifolia seeds. Physiol. Plant. 52:177180.

Comé D. 1980. Problems of embryonal dormancy as exemplified by apple embryo. Israel J. Bot. 29:145-157.
Copeland, L.O. 1976. Principles of seed science and technology. Burgess, Minneapolis.

Furutani, S.C., B.H. Zandstra, and H.C. Price. 1985. Low temperature germination of celery seeds for fluid drilling. J. Amer. Soc. Hort. Sci. 110:153-156.

Guy, C.L. and J.V. Carter. 1984. Characterization of partially purified glutathione reductase from cold hardened and nonhardened spinach leaf tissue. Cryobiology 21:454-464.

Hartmann. H.T., D.E. Kester. and F.T. Davies. Jr. 1990. Plant propagation: Principles and practices. 5th ed. Prentice-Hall, Englewood Cliffs, N.J.

Justice, O.L. and L.N. Bass. 1978. Principles and practices of seed storage. U.S. Dept Agr. Hdbk. 506.
Mastalerz, J.W. 1976. (ed.). Bedding plants: A manual on the culture of bedding plants as a greenhouse crop. 2nd ed. Pennsylvania Flower Growers Assn., Unversity Park, Pa.

Mayer, A.M. and A. Poljakoff-Mayber. 1979. The germination of seeds. 2nd ed. Pergamon, New York.

Milliken, G.A. and D.E. Johnson. 1984. Analysis of messy data. vol. 1. Design experiments. Van Nostrand-Reinhold, New York.

Steel, R.G.D. and J.H. Torrie. 1960. Principles and procedures of statistics. McGraw Hill, New York.

Styer, R.C. and S. Laffe. 1990. Tips on germinating the top ten. Greenhouse Manager 9(10): 49-41. 